\title{
Testing the devil's impact on southern Baltic and North Sea basins whitefish (Coregonus spp.) diversity
}

\author{
Thomas Mehner $^{1^{*}}$ (D) Kirsten Pohlmann ${ }^{1}$, David Bittner ${ }^{2,3}$ and Jörg Freyhof ${ }^{1}$
}

\begin{abstract}
Background: The diversity and phylogeny of whitefish of the genus Coregonus is complex, and includes many endemic species of high conservation concern. However, because of commercial importance of whitefish fisheries, stockings and translocations have occurred repeatedly, which challenges the identification of local populations as conservation units. This study analyses the phylogenetic relationships of 15 contemporary and two historical populations of lake-resident and anadromous whitefish (Coregonus spp.) from the southern Baltic and North Sea basins. We elucidated the complex history of Lake Schaal (northern Germany) whitefish, for which a local tale suggests that the devil threw whitefish from the Central European Lake Constance into this lake. Studies from the early twentieth century indeed suggested numerous stocking events for Lake Schaal from Lake Constance, from Estonian/Russian Lake Peipsi and from the anadromous whitefish of the Baltic Sea.

Results: Analyses of 13 microsatellite markers showed that Lake Constance whitefish are unrelated to any northern Germany whitefish population, including the contemporary whitefish population from Lake Schaal. Comparison with four historical specimens further showed that the native Lake Schaal whitefish (C. holsatus) vanished from the lake, but has survived as a non-native population in the north German Lake Drewitz. The whitefish currently occurring in Lake Schaal and three adjacent lakes are identified as C. maraenoides, introduced from Lake Peipsi. The contemporary anadromous whitefish populations from the Baltic (German and Finnish coast) and the German River Treene (North Sea basin, stocked from Danish River Vida) grouped together, but showed significant genetic differentiation. The 14 historical specimens of C. oxyrinchus from Rivers Rhine and Schelde were assigned to several contemporary whitefish populations, but among them only one specimen was assigned to the contemporary River Treene population. Therefore, we do not support the view that the whitefish from River Vida/Treene are identical with the historical C. oxyrinchus.
\end{abstract}

Conclusions: Our study demonstrates that lake and anadromous whitefish in the Baltic and North Sea basins reflect a complex phylogeography, which is further blurred by the effects of repeated stocking and translocations. To identify conservation units, the genetic identity of each population has to be scrutinized.

Keywords: Coregonus, Microsatellite markers, Stocking, Conservation, Admixture

\footnotetext{
* Correspondence: mehner@igb-berlin.de

${ }^{1}$ Leibniz-Institute of Freshwater Ecology and Inland Fisheries,

Müggelseedamm 310, 12587 Berlin, Germany

Full list of author information is available at the end of the article
}

(c) The Author(s). 2018 Open Access This article is distributed under the terms of the Creative Commons Attribution 4.0 International License (http://creativecommons.org/licenses/by/4.0/), which permits unrestricted use, distribution, and reproduction in any medium, provided you give appropriate credit to the original author(s) and the source, provide a link to the Creative Commons license, and indicate if changes were made. The Creative Commons Public Domain Dedication waiver (http://creativecommons.org/publicdomain/zero/1.0/) applies to the data made available in this article, unless otherwise stated. 


\section{Background}

Whitefish of the genus Coregonus represent a large group of medium to large-sized resident or migratory freshwater fishes. Their diversity and phylogeny are still largely unresolved and traditionally considered a nightmare when it comes to the recognition of species and conservation units [1-8]. Understanding the diversity of whitefish is complicated by three major problems. First, Coregonus species are notorious for postglacial $(<12.000$ years $)$ adaptive radiations $[9,10]$ and parallel evolution [11] leading to local endemic species and species flocks [12-14]. Secondly, whitefish possess only a limited number of distinguishing morphological features, certainly due to the relatively recent evolutionary divergence of many individual species and populations. The most prominent meristic character is the number of gill rakers, while other characters are more subtle and often ignored. However, the number of gill rakers may undergo rapid modifications when environmental conditions change [15], and their reliability as taxonomic character has to be assessed for each population with great care. Thirdly, due to their high commercial value, stockings from multiple origins even over large spatial distances have been reported for Coregonus since the fourteenth century [16-18], but details are usually poorly documented and stocking history is rarely retraceable. Accordingly, current populations may comprise a mix of native and introduced genotypes due to introgressive hybridization [19].

A typical example of a complex and unresolved genetic history of whitefish is the locally famous case of Lake Schaal in northern Germany (area $24 \mathrm{~km}^{2}$, maximum depth $72 \mathrm{~m}$, weakly eutrophic). At about 1920, a native origin was assumed by Thienemann [20, 21], who described the whitefish from Lake Schaal and the adjacent Lake Selenter (geographical distance about $90 \mathrm{~km}$ ) morphologically in detail and, according to the low number (23-27) of short gill rakers, named it as a species of its own, Coregonus holsatus. In 1997, Kottelat [22] suggested that $C$. holsatus from Lake Schaal might be conspecific with Coregonus widegreni, known as the valaamka whitefish, a large deepwater species from Russian Lake Ladoga, and the Scandinavian sandsik or sea-spawning whitefish [23].

However, there are numerous reports, which indicate potential stocking activities for Lake Schaal from other sources. Documentations from the 19th and early 20th centuries report the introduction of Coregonus maraena, an anadromous whitefish of Baltic Sea tributaries, into Lake Schaal [24, 25]. Surprisingly, the same authors also reported that Lake Schaal was stocked with whitefish from Lake Constance, especially Coregonus wartmanni and $C$. macrophthalmus $[16,17]$. However, the $C$. holsatus whitefish from Lake Schaal originally described by Thienemann $[20,21]$ morphologically strongly resemble a third of the Lake Constance whitefish species, Coregonus arenicolus, by their subterminal mouth, a large size of more than $450 \mathrm{~mm}$ standard length, 23-27 short gill rakers (18-27 in C. arenicolus) and a predominantly benthic foraging behaviour [18]. A potential stocking history of Lake Schaal from Lake Constance is also reflected by a local tale: An abbess in the monastery of the village Zarrentin at Lake Schaal promised her soul to the devil in return for Lake Constance whitefish during fasting. Due to strong compunctions she tricked the devil who delivered the fish from Lake Constance. The devil furiously threw the whitefish into Lake Schaal, where they were caught ever since. This myth suggests that Lake Schaal whitefish $C$. holsatus is not of native origin, but has been introduced from Lake Constance already during the period of operation of the monastery on Lake Schaal (between 1246 and 1553). Subsequently, we refer to this tale as the "devil hypothesis".

To further complicate the situation, the lake-resident Coregonus maraenoides from Lake Peipsi (Estonia/ Russia) have been introduced into Lake Schaal during the 1930s [26, 27], after the description of C. holsatus from Lake Schaal by Thienemann [20, 21]. Present-day whitefish from Lake Schaal and the nearby located Lake Selenter are morphologically similar to $C$. maraenoides (35-45 gill rakers, lower jaw slightly protruding) [28], and do no longer agree with the original description of C. holsatus $[20,21]$ or the historical C. holsatus material deposited at the Zoological Museum of Berlin, Germany (ZMB). In contrast, a large whitefish population, which matches all morphological characters with Thienemann's $[20,21]$ original description of $C$. holsatus and the corresponding material at $\mathrm{ZMB}$, exists at present in the north-east German Lake Drewitz (synonymous name Alt-Schweriner See). According to unpublished reports, whitefish, presumably C. holsatus, were translocated from Lake Schaal into Lake Drewitz in 1931, before stocking of $C$. maraenoides into Lake Schaal commenced [26].

Finally, Coregonus oxyrinchus, an anadromous whitefish from the North Sea is another potential source, which may have contributed to the stocking history of Lake Schaal. Historically, C. oxyrinchus has occurred in Rivers Rhine and Schelde, but meanwhile there is evidence that it is globally extinct [29]. Currently, whitefish from the Danish River Vida are stocked into Rivers Rhine and Treene, the latter being geographically in close proximity to Lake Schaal. There is an ongoing discussion about the genetic allocation of the River Vida whitefish, which is denominated and stocked as C. oxyrinchus [30, 31], although the genetic relationship to other anadromous whitefish populations are unresolved [29].

For nature conservation, Coregonus populations are of special importance, because they often represent unique 
species flocks $[9,10,13,32]$ or locally endemic species which are vulnerable to anthropogenic impacts [12, 14, 33]. The fragility of recent radiations to human-mediated eutrophication as well as gene flow from stocking has been highlighted for whitefish from Alpine lakes [34]. Accordingly, a valid conservation status of the current Lake Schaal population can only be obtained if genetic modification by stocking or translocation can be excluded. The phylogeography of the historical Lake Schaal whitefish population $(=C$. holsatus $)$ is still unresolved, but molecular methods may identify potential source populations to evaluate the conservation status of whitefish in this lake.

In this study, we elucidate the phylogeographic history of the Lake Schaal whitefish population in comparison with other whitefish populations by molecular markers. We test specifically whether the present Lake Schaal population is genetically most similar to species from Lake Constance (i.e. C. wartmanni, C. arenicolus, or C. macrophthalmus, the "devil hypothesis"), or is more similar to and thus may originate from other European whitefish populations (i.e. from C. maraenoides, C. maraena, $C$. oxyrinchus or $C$. widegreni). In contrast, a native origin would be supported by genetic similarity with the presumably translocated contemporary $C$. holsatus population in Lake Drewitz and by correspondence with historical C. holsatus specimens as found in ZMB. To resolve the genetic uncertainty of the River Vida whitefish population, we also included historical museum specimens of C. oxyrinchus from the Rivers Rhine and Schelde populations. By including this broad variety of potential origins and the mix of contemporary populations and historical individuals, our study is the first opportunity to review the diversity of whitefish populations from the south-western Baltic and eastern North Sea basins for conservation purposes.

\section{Methods}

\section{Coregonus species in this study}

We considered the genetic relationships among nine groups of whitefish populations to elucidate the potential origin of contemporary Lake Schaal whitefish (see overview and number of specimens per population in Table 1). At about 1920, Coregonus holsatus was only reported from the adjacent Lakes Schaal and Selenter (geographical distance about $90 \mathrm{~km}$ ), and therefore we obtained specimens of the contemporary populations from these two lakes. There was no distinct information about the presence of $C$. holsatus in other nearby lakes in north-west Germany, but we included samples from whitefish populations in Lakes Poenitzer and Keller, both adjacent to Lake Selenter. These four lakes form the first

Table 1 Overview on Coregonus populations analysed

\begin{tabular}{|c|c|c|c|c|c|c|}
\hline Population origin & Species & $\mathrm{N}$ & $A_{N}$ & $A_{R}$ & $F_{I S}$ & P Het \\
\hline \multicolumn{7}{|l|}{ Contemporary populations } \\
\hline O1_Lake Selenter & C. maraenoides & 30 & 8.8 & 5.4 & 0.099 & $<0.0001$ \\
\hline O1_Lake Keller & C. maraenoides & 24 & 7.6 & 4.8 & 0.188 & $<0.0001$ \\
\hline O1_Lake Poenitzer & C. maraenoides & 32 & 7.8 & 5.0 & 0.147 & $<0.0001$ \\
\hline O1_Lake Schaal & C. maraenoides & 50 & 9.8 & 5.2 & 0.159 & $<0.0001$ \\
\hline O2_Lake Peipsi & C. maraenoides & 18 & 7.0 & 4.9 & 0.048 & 0.033 \\
\hline O3_Lake Drewitz & C. holsatus & 20 & 5.5 & 3.9 & 0.134 & 0.002 \\
\hline O4_Achterwasser & C. maraena & 24 & 7.0 & 4.7 & 0.057 & 0.001 \\
\hline O4_River Schlei & C. maraena & 20 & 6.1 & 4.2 & 0.041 & 0.025 \\
\hline O4_River Trave & C. maraena & 30 & 7.3 & 4.9 & -0.004 & 0.617 \\
\hline O5_Oulu (Baltic Sea) & C. widegreni & 25 & 9.0 & 5.5 & 0.072 & $<0.0001$ \\
\hline O6_River Treene & C. cf. maraena & 20 & 6.2 & 4.4 & 0.072 & 0.007 \\
\hline O7_Lake Constance_Blaufelchen & C. wartmanni & 7 & 3.8 & 3.4 & 0.060 & 0.222 \\
\hline O7_Lake Constance_Sandfelchen & C. arenicolus & 9 & 3.5 & 3.1 & 0.029 & 0.119 \\
\hline O7_Lake Constance_Weißfisch & C. macrophthalmus & 16 & 4.2 & 3.3 & 0.165 & $<0.0001$ \\
\hline O7_Lake Constance_Gangfisch & C. macrophthalmus & 18 & 5.2 & 3.8 & 0.270 & $<0.0001$ \\
\hline \multicolumn{7}{|l|}{ Historical samples } \\
\hline O8_Lakes Schaal, Selenter & C. holsatus & 4 & & & & \\
\hline O9_Rivers Rhine, Schelde & C. oxyrinchus & 14 & & & & \\
\hline Total & & 361 & & & & \\
\hline
\end{tabular}

Origin 01-07: contemporary, origin 08-09 historical whitefish (Coregonus) populations. Lake or river origin, scientific name, sample size (N), mean number of alleles $\left(A_{N}\right)$, mean allelic richness normalized to a sample size of $N=7\left(A_{R}\right)$, inbreeding coefficient $\left(F_{I S}\right)$, P-values for heterozygote deficits $(P$ Het $)$ 
group of potential origin (O1, Fig. 1, Additional file 1: Table S1). We further included C. maraenoides from Russian/Estonian Lake Peipsi (group O2, Fig. 1), which were introduced into Lake Schaal during the 1930s [26]. Whitefish from Lake Drewitz, which probably originate from Lake Schaal [26], form the third group (O3, Fig. 1).
Since the introduction of C. maraena into Lake Schaal is also possible, we included three C. maraena populations, originating from the German Baltic Sea coast (Achterwasser) and the Rivers Schlei and Trave, both draining into the Baltic Sea (group O4, Fig. 1, Additional file 1: Table S1). In 1997, Kottelat [22] suggested that $C$.

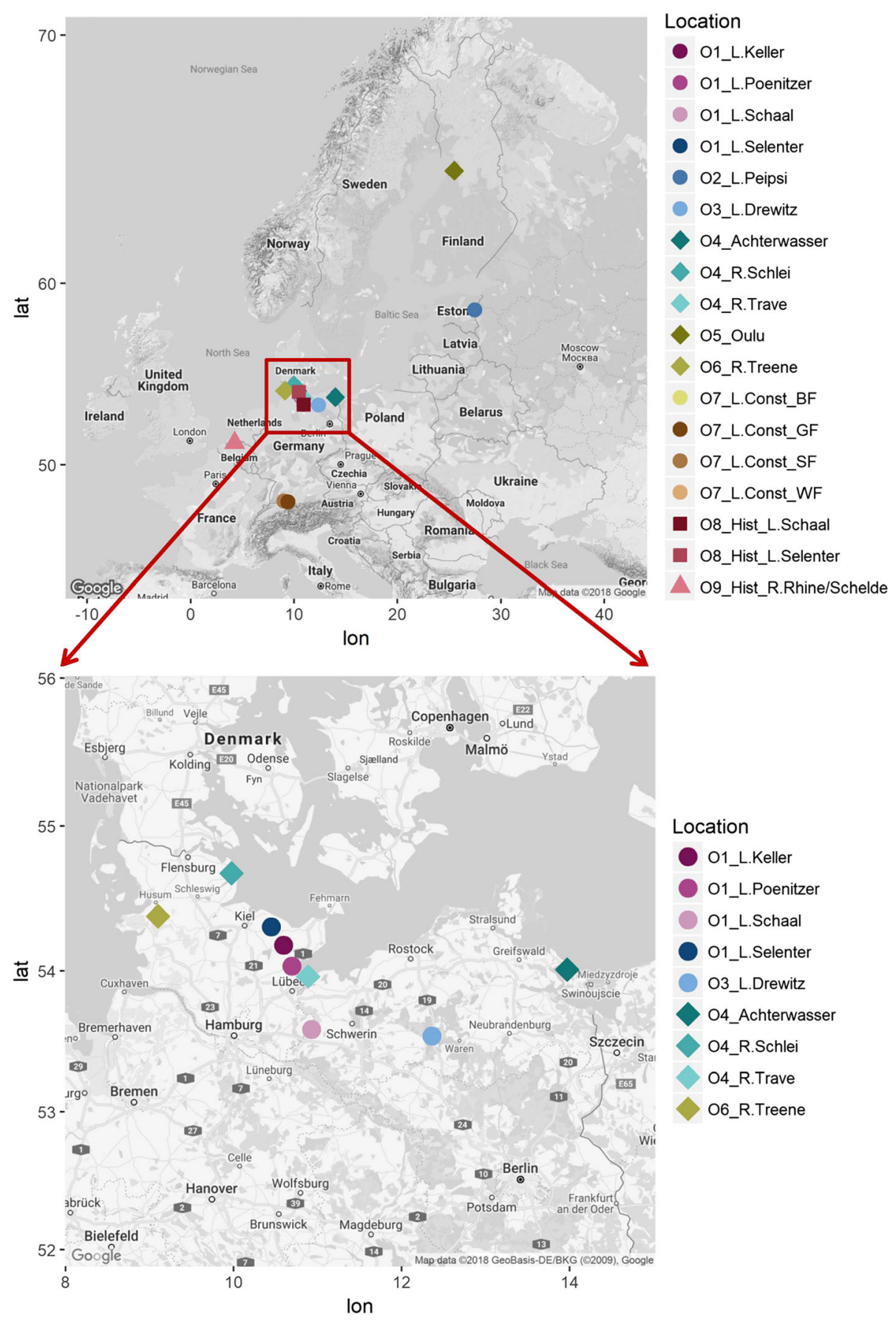

Fig. 1 Geographical map of Europe, showing the sampling locations of 15 contemporary and 2 historical whitefish populations, accumulated into nine groups of origin (01-09, upper panel), and locations of population origin in northern Germany (lower panel). Lake-resident populations are indicated by circles, whereas anadromous populations are indicated by diamonds. Historical lake populations are indicated by squares and historical anadromous population by triangles. For details of populations, see Table 1 
holsatus and $C$. widegreni might be related and indeed, Baltic C. widegreni might have invaded Lakes Schaal and Selenter after the last glaciation. We thus further elucidated the phylogenetic relationship of the Lake Schaal population to C. widegreni obtained from the Baltic Sea coast near Oulu, Finland (group O5, Fig. 1). We also sampled contemporary Danish River Vida whitefish, which are stocked into the German River Treene (draining into the North Sea) [35] (referred to as C. cf. maraena) (group O6, Fig. 1). To test the "devil hypothesis", we added samples of all four Lake Constance whitefish populations (i.e. C. wartmanni, C. arenicolus, and C. macrophthalmus from Upper and Lower Lake Constance, group O7, Fig. 1, Table 1, Additional file 1: Table S1). After having resolved the genetic structure among these 15 contemporary populations, we compared the molecular markers of historical specimens (obtained from museums) of $C$. holsatus from Lakes Schaal and Selenter $(N=4$, group O8, Fig. 1), and of historical C. oxyrinchus from the Rivers Rhine and Schelde $(N=14$, group O9, Fig. 1, Additional file 1: Table S1) with the genetic signatures of the contemporary populations.

\section{Sampling}

All fish from contemporary populations were obtained from local fishermen immediately after catch in 2004 and 2005. One pectoral fin per fish was clipped and instantaneously fixed in ethanol for genetic analyses. All samples were identified to species by JF. Voucher material of all whitefish analysed is deposited in the Zoological Museum of Berlin, Germany (ZMB). From Lake Peipsi we obtained tissue from eight fish only, but successfully extracted DNA from dried scales of another 10 individuals. Historical tissue material from $C$. holsatus originates from the ZMB: two individuals from Lake Selenter and two from Lake Schaal. Origin of historical tissue material from 14 C. oxyrinchus specimens caught in Rivers Rhine and Schelde is listed by Freyhof \& Schöter [29].

\section{Microsatellite analysis}

Total DNA was extracted from fin tissue using the QIA$\mathrm{GEN}^{\circ}$ DNeasy kit following the protocol of the supplier. For historical samples, the tissue was soaked in repeatedly changed TE buffer for $48 \mathrm{~h}$ prior to extraction and the concentration of proteinase $\mathrm{K}$ and the time of tissue digestion was tripled for extraction [36]. DNA concentration was determined spectrographically and aliquots diluted to a final concentration of $\sim 20 \mathrm{ng}^{-1}$ (100 ng $\mathrm{\mu l}^{-1}$ for historical samples). All individuals were typed at 11 polymorphic microsatellites following the protocol developed by Bittner et al. [15], supplemented by two further microsatellite loci. The two multiplex sets, i.e. simultaneous PCR amplification of multiple markers, were composed of the following loci: set 1 consisted of
C2-157 [37], CoCl6, CoCl10, CoCl49, CoCl61, CoCl68 [38], and BWF1 [39]; set 2 contained CoCl4, CoCl18, CoCl45, CoCl224 [38], BWF2 [40], and CoCl-Lav52 [38]. The forward primers were labelled with fluorescent dyes (Applied Biosystems Inc., ABI): $\mathrm{C} 2-157$ and $\mathrm{CoCl} 18$ with $\mathrm{PET}^{\mathrm{m}}{ }^{\mathrm{m}}, \mathrm{CoCl} 6, \mathrm{CoCl} 10$ and $\mathrm{CoCl} 4$ with $\mathrm{NED}^{\mathrm{m} \text {, }}$, BWF1, CoCl68, BWF2 and CoCl45 with VIC ${ }^{\mathrm{mm}}$, CoCl49, CoCl61, CoCl224, and CoCl-Lav52 with 6-FAM ${ }^{\mathrm{mm}}$. The Qiagen Multiplex PCR kit was used for PCR amplification according to the recommendations of the manufacturer.

PCR amplification was carried out in $10 \mu \mathrm{l}$ reaction volumes, containing $5 \mu$ l QIAGEN $^{\bullet}$ Multiplex PCR mastermix, $3 \mu \mathrm{l} \mathrm{H}_{2} \mathrm{O}$ (PCR grade), $1 \mu \mathrm{l}$ DNA $\left(\sim 20 \mathrm{ng} \mu \mathrm{l}^{-1}\right)$ and $1 \mu \mathrm{l}$ Primermix $\left(\sim 2 \mathrm{pmol} \mu \mathrm{l}^{-1}\right.$ each primer). The thermocycling profile started with an initial denaturation step at $95^{\circ} \mathrm{C}$ for $15 \mathrm{~min}$, followed by 30 cycles of $30 \mathrm{~s}$ at $94{ }^{\circ} \mathrm{C}, 90 \mathrm{~s}$ at $57^{\circ} \mathrm{C}, 90 \mathrm{~s}$ at $72{ }^{\circ} \mathrm{C}$ and ended with a final extension step of $10 \mathrm{~min}$ at $72^{\circ} \mathrm{C}$. A quantity of $1.5 \mu \mathrm{l}$ of a 1:2 dilution of the PCR reaction were added to a mix of $19 \mu \mathrm{l} \mathrm{Hi-Di}$ Formamide (ABI) and $1 \mu \mathrm{l} \mathrm{L^{ \textrm {m } }}{ }^{\mathrm{m}}$ size standard (ABI), and denatured fragments were resolved on an automated DNA sequencer (ABI 3100). Genotypes were determined with the software Gene Mapper ${ }^{\mathrm{ru}}$ version 4.0 (Applied Biosystems Inc). As a quality control for PCR and fragment analyses, DNA of two already previously genotyped individuals was amplified and analysed with any batch of 94 individuals. If loci or alleles of these two control samples were missing or differed from previous results, the fragment analysis was repeated for all samples per batch. If still alleles were missing, the PCR and fragment analysis were repeated. Analyses of individuals with missing genotypes (at one or several markers) were also repeated until completion in a similar fashion. To estimate repeatability in addition, 9.7\% (35 of the 361 individuals) were analysed twice at all 13 loci and 10 mismatches were found, which relates to an overall genotyping error rate of $2.2 \%$, not accumulated on specific loci.

\section{Statistical data analyses}

All analysis and graphical output were performed in $\mathrm{R}$ version 3.4.2 [41]. Genetic diversity was quantified as mean number of alleles $A_{N}$ and allelic richness $A_{R}$, i.e. the allele number corrected for the smallest sample size among contemporary populations $(N=7)$ [42], by PopGenReport 3.0 [43]. Allele frequency-based correlations (inbreeding coefficient $\mathrm{F}_{\mathrm{IS}}$ ) and population-wide deviations from Hardy-Weinberg equilibrium (HWE) were tested by the exact (probability) test using genepop_in_R based on GENEPOP 4.7.0 [44, 45]. The probabilities for locus-specific deviations from HWE [46] per population were corrected by the false discovery rate for multiple tests [47], completed by U-tests on excess of homozygotes. Finally, a global test for linkage disequilibrium 
between loci as based on the index of association with an approximation for the number of loci $\mathrm{rD}$ [48] was run in poppr 2.81.1 [49,50].

To infer population structure by determining the number of clusters observed without prior knowledge, we applied Discriminant Analysis of Principal Components (DAPC) [51, 52], a model-free approach, which therefore does not require panmictic populations and unlinked markers [52]. DAPC aims to provide an efficient description of genetic clusters using a few synthetic variables. These are constructed as linear combinations of the original variables (alleles) which have the largest betweengroup variance and the smallest within-group variance. To define the number of principal components (PCs) retained in the analysis, we applied cross-validation which provides an objective optimization procedure for identifying the trade-off between retaining too few and too many PCs in the model. These calculations were run in adegenet 2.1.0 $[53,54]$. From the DAPC, individual membership probabilities for fish from the 15 contemporary populations could be calculated as based on the retained discriminant functions, which are the linear combinations of original variables. To contrast within- and between-population variance for the 15 contemporary populations, we ran Analysis of Molecular Variance (AMOVA) [55] as implemented in the R-package 'pegas' [56].

To account for potential bias in individual assignment to DAPC-clusters from locus-specific deviations from HWE, we re-run the DAPC without the four loci showing the most frequent deviations from HWE (see results). Subsequently, we estimated the probability of assignment to the population of origin for each individual, and calculated the mean self-assignment for each population. The mean self-assignment as based on all 13 loci was compared with the mean self-assignment as based on the 9 loci excluding those with substantial deviations from HWE by Pearson's correlation.

Population differentiation was estimated by F-statistics [57] between populations (pairwise $\theta$ ). Significance of differentiation was assessed through the calculation of $95 \%$ confidence intervals (CI) using a bias-corrected bootstrapping method with 1000 permutations in DiveRsity 1.9.90 [58], with CIs including zero considered non-significant.

Furthermore, using the allele loadings, the individuals from historical populations (which have been excluded from the DAPC analysis) could be plotted onto the factorial DAPC plane, and we could derive their membership probabilities to the defined clusters. To support the DAPC analyses on historical individuals, we ran an alternative likelihood-based assignment procedure in Geneclass2 [59], as based on the Bayesian criterion by Baudouin \& Lebrun [60].

Finally, to detect genetic relationships among all 15 contemporary and two historical populations, Nei's genetic distances $\left(D_{A}\right)[61]$ were depicted as an unrooted neighbor-joining (NJ) dendrogram using poppr 2.6.1. [49]. To infer the effect of locus-specific deviations from HWE, another NJ dendrogram was calculated as based on the reduced number of 9 loci.

\section{Results}

\section{Genetic structure within populations}

Sample sizes were different between populations (range 7-50 within contemporary populations, Table 1). All microsatellites were variable in all populations, with $7-$ 33 alleles per locus across all populations. Allelic richness $A_{R}$, the mean number of alleles per locus and population adjusted to the minimum $N=7$, varied little among populations (Table 1). The lowest mean values (3.1-3.8) were found in Lake Constance whitefish which had the smallest sample sizes, and the highest value (5.5) was found in $C$. widegreni from the Baltic Sea coast (Oulu). In all but one sample, the expected heterozygosity across all loci was higher than the observed heterozygosity (i.e. $F_{\text {is }}>0$, see Table 1 ). U-tests revealed significant heterozygote deficiencies in all populations except for C. wartmanni and C. arenicolus from Lake Constance and C. maraena from River Trave.

The number of deviations from HWE tested individually for all 13 analyzed microsatellite loci and corrected by the false discovery rate for multiple tests varied between populations (Additional file 1: Table S2). The C. maraenoides population from Lake Schaal and the C. maraena populations of Rivers Schlei and Trave had deviations from HWE in four microsatellites, whereas C. widegreni (Oulu) and C. c.f. maraena from River Treene did not show any deviation from HWE (Additional file 1: Table S2). Most deviations from HWE occurred in the markers BWF1 $(N=7)$, BWF2 $(N=6), C 2-157(N=4)$ and CoCl224 $(N=3)$ (Additional file 1: Table S2). Therefore, we repeated several subsequent tests by excluding these four loci (see below). The global test for linkage disequilibrium indicated that the alleles were weakly linked across the 13 loci $(\mathrm{rD}=0.023, P=0.001$ based on 999 permutations). The strongest associations were found between the loci $\mathrm{CoCl} 18$ and $\mathrm{CoCl} 4$ $(\mathrm{rD}=0.092)$, BWF1 and CoCl61 $(\mathrm{rD}=0.086)$ and between $\mathrm{CoCl} 4$ and $\mathrm{CoCl} 61(\mathrm{rD}=0.082)$.

\section{Genetic structure between populations}

Discriminant Analysis of Principal Components (DAPC) was run with the cross-validated optimum number of 80 principal components (cumulated variance 93.2\%) and six discriminant functions and differentiated the 343 individuals from the 15 contemporary populations along the first two discriminant axes (Fig. 2a). All four Lake Constance whitefish populations were separated from the other 11 populations along axis 1 . Along axis $2, C$. 


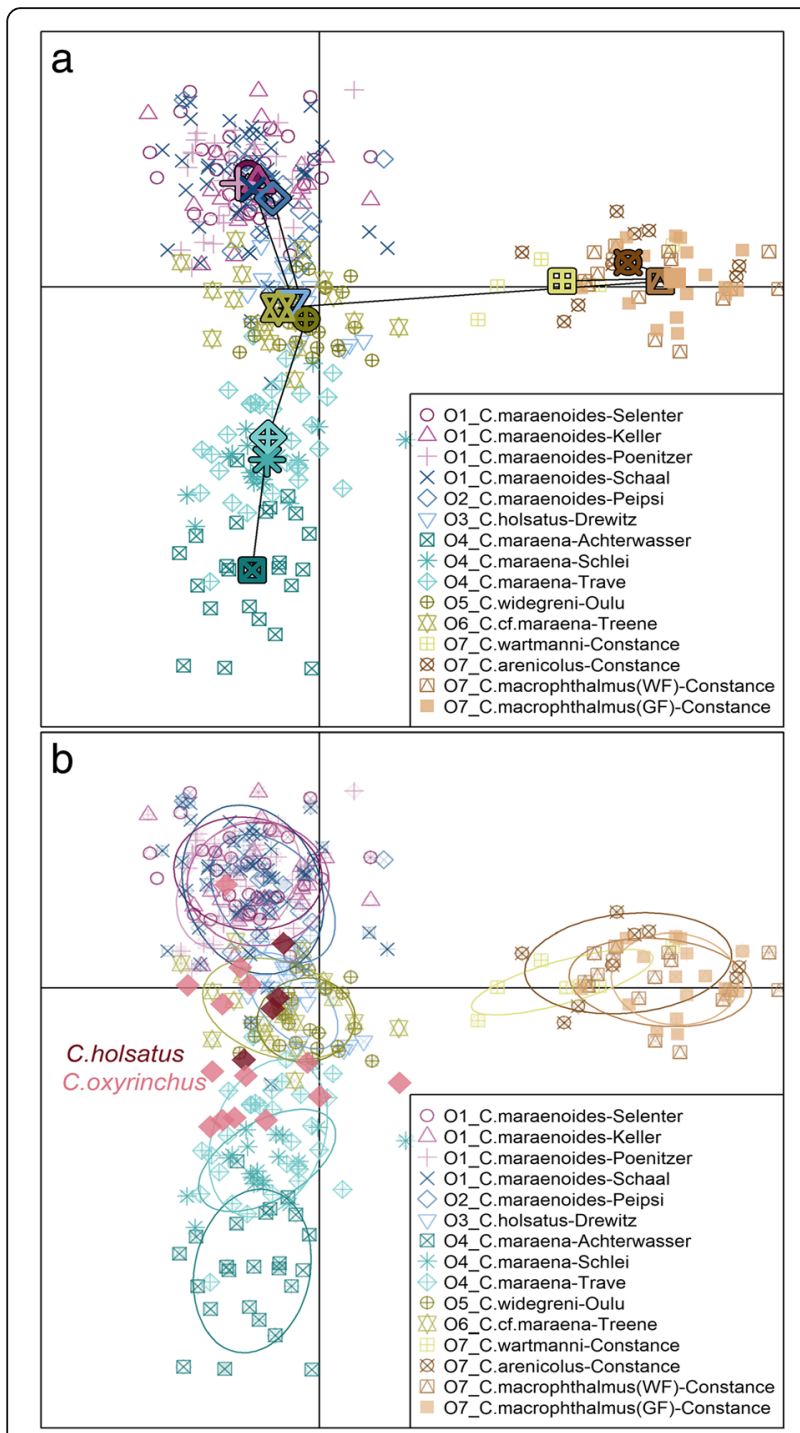

Fig. 2 a Axes 1 and 2 of Discriminant Analysis of Principal Components (DAPC) of the 343 individuals of whitefishes from 15 contemporary populations. The center of each group is indicated by large symbols, the minimum spanning tree based on the (squared) distances between populations within the entire space is indicated by lines. $\mathbf{b}$ The same as in A, but populations reflected as inertia ellipses, and the 18 historical individuals from two populations (C. holsatus from Lakes Schaal and Selenter, $N=4$, and C. oxyrinchus from Rivers Rhine and Schelde, $N=14$ ) obtained from museums plotted onto the DAPC plane. For population names and geographical origin (O1-O9), see Table 1

maraena from Achterwasser and Rivers Trave and Schlei were opposed to the northern whitefish populations from the German Lakes Schaal, Poenitzer, Keller and Selenter and the Russian/Estonian Lake Peipsi. Lake Drewitz whitefish, C. widegreni (Oulu) and C. cf. maraena from River Treene were placed in between $C$. maraena and northern lake whitefish populations (Fig. 2a). Pairwise $\theta$ was significantly larger than zero for all population pairs except between some populations of the north-German lakes (Lakes Schaal, Poenitzer, Keller, Selenter, and Russian/Estonian Lake Peipsi) and among Lake Constance C. macrophthalmus and the other three Lake Constance populations, as indicated by $95 \%$ CI of $\theta$, which included zero for these pairs (Additional file 1: Table S3). AMOVA indicated that the among-populations variance $(10.3 \%$, d.f. $=14, P<0.0001)$ was greater than the among-individuals within-populations variance $(9.1 \%$, d.f. $=328, \mathrm{P}<0.0001)$.

Individual membership probabilities, as calculated from the DAPC, indicated strong admixture between the four north German lake whitefish populations (Lakes Selenter, Keller, Poenitzer, Schaal) and Lake Peipsi (Fig. 3). Mean individual self-assignment to the population of origin in this group of lakes ranged between 28\% (Lake Keller) and 54\% (Lake Selenter). In contrast, all whitefish from Lake Drewitz, Oulu and River Treene had mean individual self-assignment rates $>95 \%$. Some admixture was also documented between the four populations from Lake Constance (mean self-assignment rates between 50 and 82\%) (Fig. 3). There were a few single individuals with strongly deviating membership probabilities relative to their population of origin (Fig. 3). For example, two individuals of the C. maraenoides population of Lake Schaal were assigned to C. maraena from River Trave, and one individual from the $C$. maraenoides Lake Peipsi population was primarily assigned to $C$. widegreni from Oulu. Furthermore, potential admixture between $C$. maraena from River Trave, $C$. widegreni from Oulu and $C$. cf. maraena from River Treene was suggested for a few individuals (Fig. 3).

To verify that deviations from HWE did not contribute substantially to the individual assignments, we repeated the DAPC by excluding the four loci with most frequent HWE deviations. There was a strong correlation between the mean individual self-assignment rates as based on the DAPC of 9 loci and the self-assignment based on all 13 loci (Pearson's $r=0.92, P<0.0001$ ). For most of the populations, the mean self-assignment rate slightly declined by excluding the four loci, but remained $>90 \%$ for whitefish from Lake Drewitz and River Treene (Fig. 4).

When the 18 historical individuals were plotted onto the DAPC plane, the four C. holsatus samples from Lakes Schaal and Selenter were located close to the contemporary Lake Drewitz and northern lake whitefish populations, whereas the 14 historical $C$. oxyrhinchus samples were scattered more broadly along axis 2 (Fig. 2b). The four historical C. holsatus individuals were all assigned by $100 \%$ to the contemporary Lake Drewitz population (Fig. 5a). In contrast, only seven of the 14 historical C. oxyrinchus individuals were assigned with $>90 \%$ probability to one of the contemporary populations $(N=5$ to $C$. maraena from 


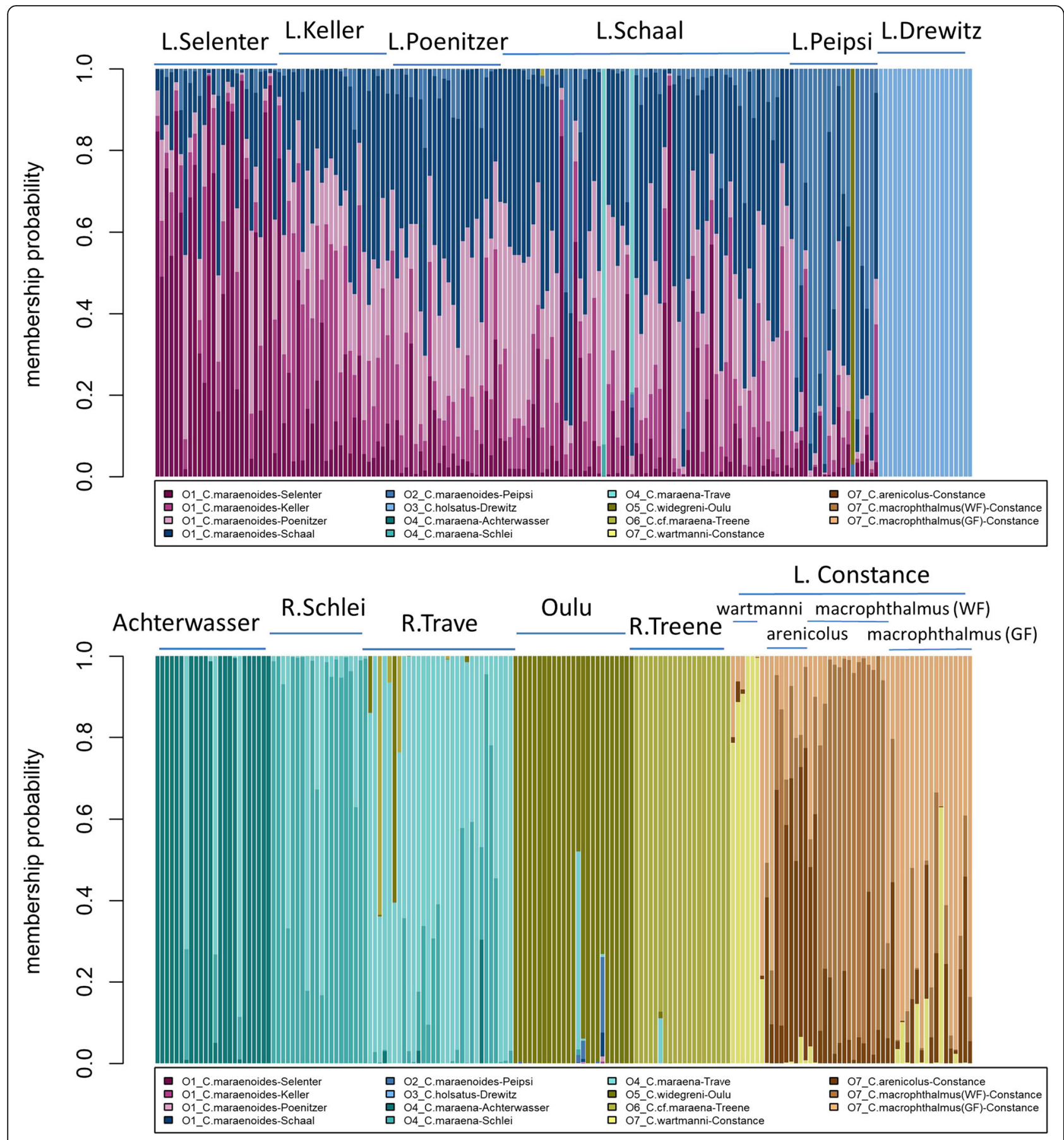

Fig. 3 Individual membership probabilities as obtained from the Discriminant Analysis of Principal Components of 343 individuals from the 15 contemporary populations of whitefish. Columns represent individuals and the different colours within each column represent the probability of membership of that individual to a specific population, as indicated in the legend. Sampling locations of the individuals are indicated above the bars

River Trave (4) or Achterwasser (1), $N=1$ to C. c.f. maraena from River Treene, $N=1$ to $C$. widegreni from Oulu) (Fig. 5a). For the remaining seven individuals, maximum assignment to any contemporary lake or anadromous population did not exceed 67\% (Fig. 5a). An alternative likelihood assignment of the historical samples as based on Geneclass 2 confirmed the $100 \%$ correspondence between historical C. holsatus and contemporary Lake Drewitz whitefish (Fig. 5b). By Geneclass2, six out of 14 historical C. oxyrinchus were dominantly assigned to River Trave, and two out of 14 to River Treene (Fig. 5b). The remaining six historical $C$. oxyrinchus were dominantly 


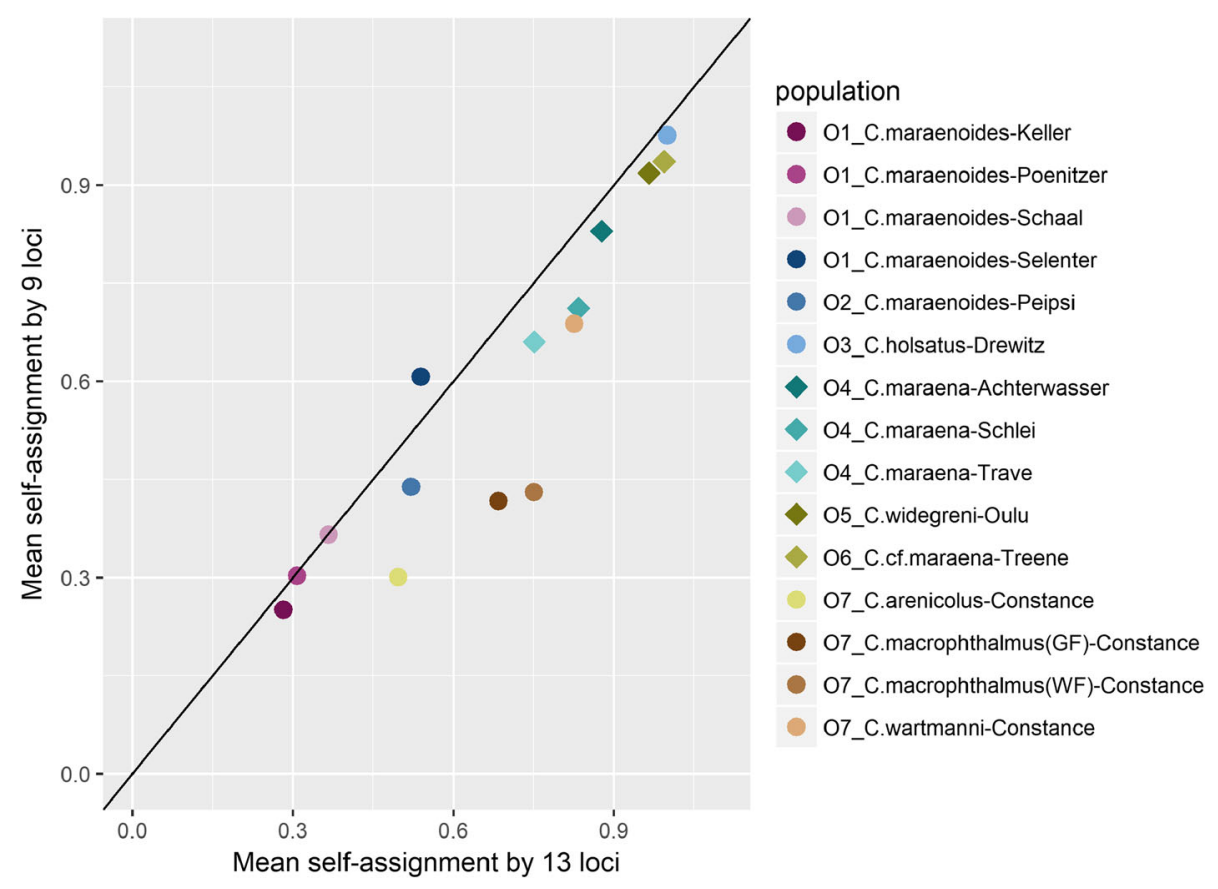

Fig. 4 Mean individual self-assignment to the population of origin as obtained from the Discriminant Analysis of Principal Components of 343 individuals from the 15 contemporary populations of whitefish, based on either all 13 microsatellites ( $x$-axis) or by excluding the four microsatellites with strong deviations from Hardy-Weinberg equilibrium (y-axis). Lake-resident populations are indicated by circles, whereas anadromous populations are indicated by diamonds. Data points are slightly jittered vertically to avoid overplotting. The black line represents the line of identity $(1: 1)$
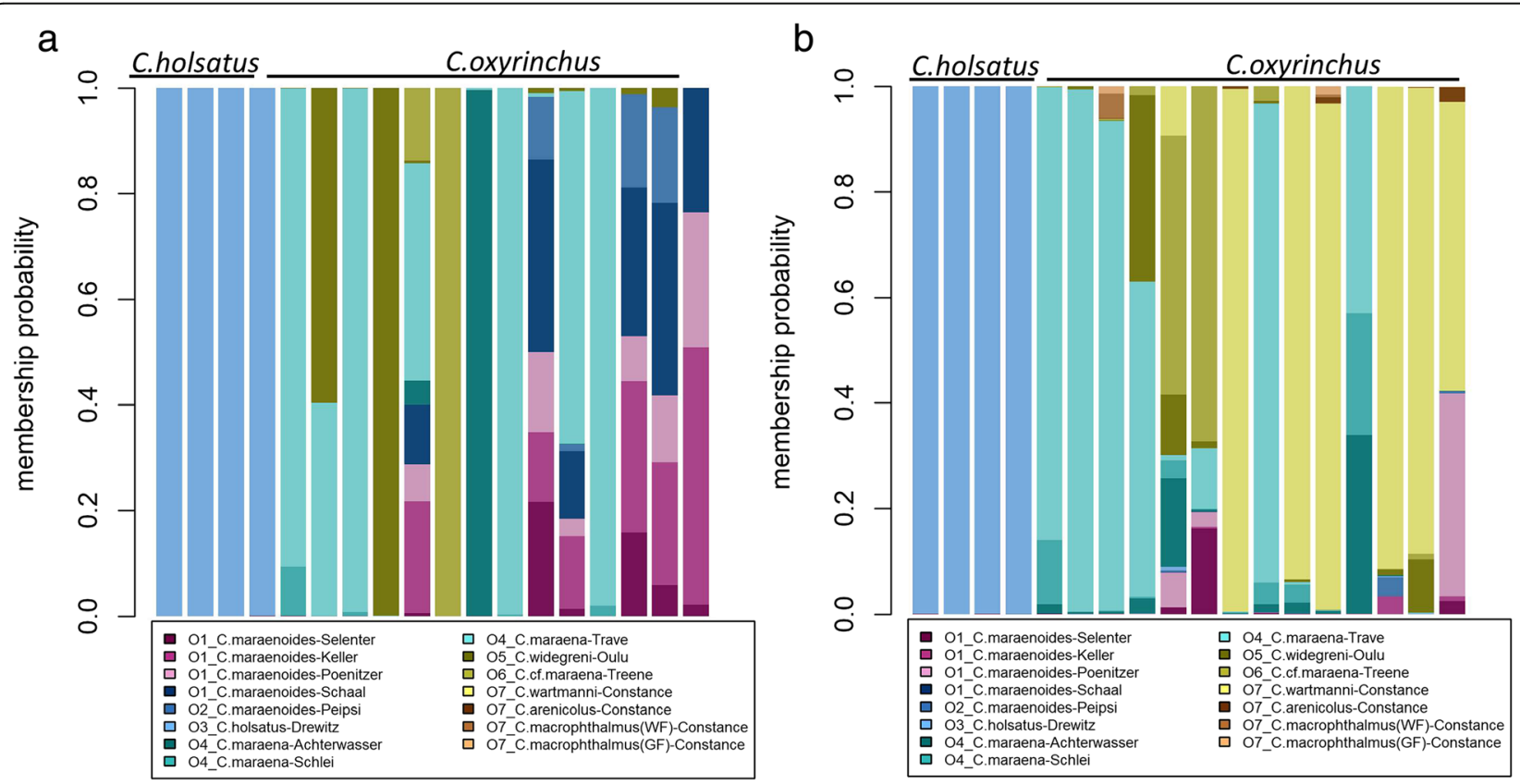

Fig. 5 Individual membership probabilities as obtained from the Discriminant Analysis of Principal Components (a) or ranked likelihoods by Bayesian assignment in Geneclass2 (b) of 18 individuals from the historical populations of whitefish ( $N=4$ lake-resident C.holsatus, $N=14$ anadromous C. oxyrinchus). Columns represent individuals and the different colours within each column represent the probability of membership of that individual to a specific contemporary population, as indicated in the legend 
assigned to Lake Constance C. wartmanni (Fig. 5b), in contrast to the assignment by DAPC, which found higher probabilities of assignment to north-German lake populations (i.e., to C. maraenoides, Fig. 5a).

Similarities of the 15 contemporary and two historical populations were finally depicted as an unrooted neighbor-joining phylogram of Nei's genetic distance (Fig. 6). Lakes Schaal and Peipsi were grouped together, with low support (bootstrap value 39\%) of branching (Fig. 6a). In contrast, Lake Selenter was grouped closer to Lake Drewitz, but with low support (31.3\%). Historical and contemporary C. holsatus (Lake Drewitz) were only weakly segregated from the north German Lakes Keller, Schaal, Poenitzer, Selenter and Russian/Estonian Lake Peipsi (31.3\%), but more strongly segregated (69.4\%) from Lake Constance whitefish and from the anadromous whitefish populations (Fig. 6a). The historical C. oxyrinchus grouped closest with $C$. maraena from Achterwasser and Rivers Schlei and Trave with moderate bootstrap support (64.7\%).
River Treene C.cf. maraena grouped with Lake Constance whitefish populations (61.5\%). However, the overall segregation between all anadromous populations and Lake Constance whitefish was weak (29.7-40.6\%, Fig. 6a). If the four loci deviating most frequently from HWE were removed, the NJ-tree remained essentially identical (Fig. 6b). However, River Treene C.cf. maraena grouped closer to historical C. oxyrinchus and C. maraena from Achterwasser and Rivers Schlei and Trave. Nevertheless, the overall segregation between all anadromous populations and Lake Constance whitefish remained weak (range of bootstrap supports $14.4-34.1 \%$, Fig. 6b).

\section{Discussion}

Our results demonstrate that the contemporary whitefish population of Lake Schaal is non-native, and does no longer correspond to the originally described $\mathrm{C}$. holsatus from this lake. The most likely origin of the fish currently occurring in Lake Schaal is Lake Peipsi $(=C$.

\section{a}

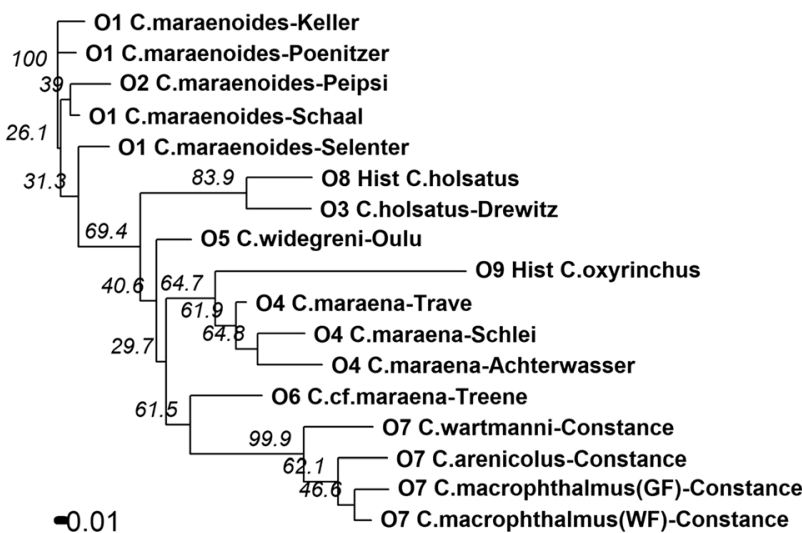

b

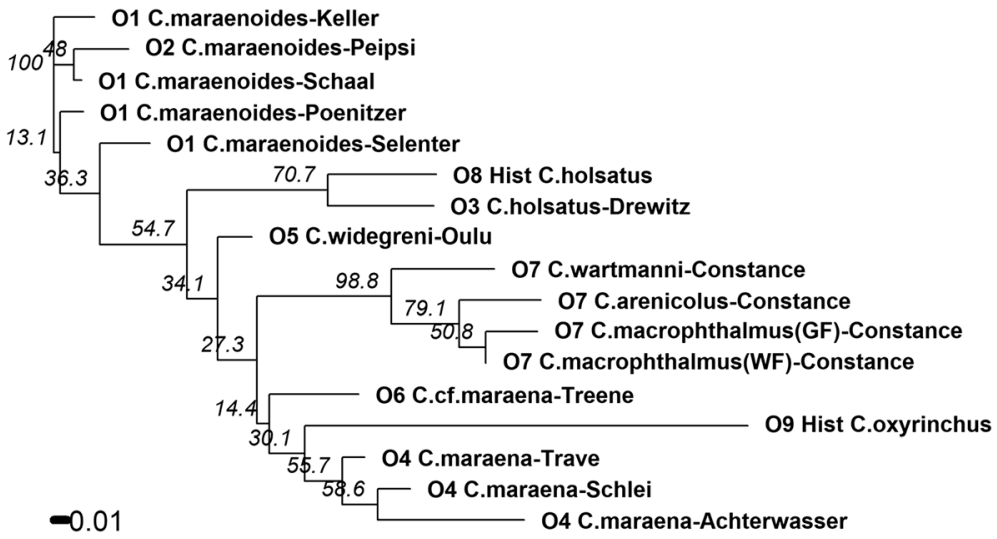

Fig. 6 Unrooted neighbor-joining phylogram of the 15 contemporary and two historical (Hist) whitefish populations based on Nei's standard genetic distance, calculated for 13 microsatellites (a), and the same phylogram calculated by excluding the four loci with strong deviations from Hardy-Weinberg equilibrium (b). Numbers represent bootstrap values based on 1000 repetitions. For population names and groups of geographical origin (01-09) see Table 1 
maraenoides), from which whitefish was stocked into Lake Schaal. A historical translocation of whitefish from Lake Constance into Lake Schaal (the "devil hypothesis") could not be confirmed, because the molecular markers of both contemporary (C. maraenoides) and historical (C. holsatus) Lake Schaal whitefish were distinct from those of all four contemporary Lake Constance populations. Furthermore, there is no genetic evidence that anadromous whitefish populations of the Baltic and North Sea basins (= C. maraena) contributed to stocking in Lake Schaal. These studied anadromous whitefish are genetically closely related, but none of them was genetically truly identical with $C$. oxyrinchus historically occurring in the Rivers Rhine and Schelde, supporting the view of Freyhof \& Schöter [29] that C. oxyrinchus is extinct. Accordingly, our application of genetic markers to a mixture of contemporary and historical samples may guide future conservation practice to protect evolutionarily significant whitefish populations.

The population structure found by all applied statistical methods was fairly similar. Both the dendrogram as based on Nei's genetic distances between populations and the individual-based DAPC showed strong allelic differences in particular between Lake Constance whitefishes, the whitefishes from north German lakes $(=C$. maraenoides), and C. maraena. Accordingly, it is unlikely that the limitations of the dataset with in part small sample sizes and strong deviations from HWE have biased the results. This conclusion is supported by the additional analyses, which excluded the four loci most frequently deviating from HWE. Both the mean proportion of self-assignment in the DAPC, reflecting the individual level, and the NJ tree of genetic distances, reflecting the population level, remained almost unchanged when the analyses were repeated with nine instead of 13 loci.

The reasons for the substantial heterozygote deficits at some loci and the weak, but significant global linkage disequilibrium are not clear. The quality control of the genotyping procedures did not reveal any technical abnormalities. Strong deviations from HWE were found in particular in whitefish populations that have been stocked repeatedly (Lake Schaal, Lake Constance, Rivers Schlei and Trave). Heterozygote deficits may be caused by population substructuring (Wahlund effect) [62, 63], and Wahlund effects have been documented repeatedly in lake populations of the Salmoniformes order [64-66]. Stocking may contribute to population substructures if natural reproduction in the system is maintained and stocked and naturally reproduced individuals do not form panmictic populations because of local adaptation and polymorphism. It is possible that potential population substructures were not adequately covered by our samples, because genotyped individuals were taken from the commercial fisheries catches, and not obtained by 3D stratified sampling as recommended for polymorphic populations [67].

We found evidence for the existence of six genetically distinct groups of whitefish populations. The first three groups consisted of the four Lake Constance populations, the three $C$. maraena populations and the five combined north German lake and Lake Peipsi populations $(=C$. maraenoides $)$. These three groups separated clearly on the DAPC plane. In addition, whitefish from Lake Drewitz $(=C$. holsatus $)$, Oulu $(=C$. widegreni $)$ and River Treene $(=C$. cf. maraena) each were depicted as different populations by significant $\theta$ in pairwise comparisons and the highest proportions of individual self-assignment, although these populations grouped closely together on the DAPC plane. Most importantly in the context of this study, all Lake Constance whitefish were clearly distinguished from the contemporary Lake Drewitz whitefish and the historical C. holsatus from Lakes Schaal and Selenter. This unambiguously falsifies the assumption of Winkler et al. [68] that historical C. holsatus from Lakes Schaal and Selenter originate from stocking of whitefish from Lake Constance. Therefore, we have to reject the "devil hypothesis" finding no support that C. holsatus was based on introduced Lake Constance whitefish.

For conservation purposes, $C$. holsatus was accordingly preliminarily treated as a unique and endemic conservation unit classified as "extinct in the wild" [33] as it did not survive within its native historical range. The extinction in Lake Schaal was confirmed by our molecular data. However, the original $C$. holsatus has survived by translocation. Due to the clear morphological and genetic similarities of contemporary Lake Drewitz whitefish with the four historical $C$. holsatus specimens we classify contemporary Lake Drewitz whitefish as $C$. holsatus and confirm that C. holsatus from Lake Schaal was the initial source for the introduced and presently established whitefish in Lake Drewitz [26]. The genetical assignment of the historical C. holsatus from Lakes Schaal and Selenter to contemporary C. holsatus from Lake Drewitz was independently found by two statistical approaches (DAPC and Geneclass2), and hence is considered reliable. The whitefish in Lake Drewitz have to be classified as non-native since this species did not inhabit the lake historically. Nevertheless, Lake Drewitz whitefish have to be protected from any kind of stocking or other management endangering the genetic integrity of the species.

The contemporary Lake Schaal whitefish and the whitefish in the nearby northern German lakes (Poenitzer, Keller, and Selenter) can be identified as Lake Peipsi whitefish $C$. maraenoides, in contrast to the common designation as European lake whitefish C. lavaretus (e.g., [69]). C. maraenoides has been stocked to various lakes 
in north western Germany since the 1930s [26, 27], and has obviously replaced $C$. holsatus in Lake Schaal, and to a lesser extent also in Lake Selenter. The temporal and causal aspects of these replacements are unknown. It is possible that C. maraenoides outcompeted C. holsatus, or that both species hybridized to some extent, or that C. holsatus declined due to the eutrophication of both lakes in the twentieth century [70] before or after stocking with C. maraenoides. Consequently, following Winkler et al. [68], it can be recommended to exclude the contemporary Lakes Schaal (and Selenter) whitefish from national conservation efforts due to their presumed non-native origin.

The fact that the four historical individuals of C. holsatus from Lakes Schaal and Selenter were projected close to the whitefish from Lake Drewitz but also close to the contemporary north German lake populations (i.e., $C$. maraenoides) onto the DAPC plane may point to the presence of some remnant hybridized genetic material in the contemporary Lakes Schaal and Selenter populations. Admixture with stocked material was also suggested by the membership probabilities as calculated from the DAPC, and by the weak bootstrap support of branching between $C$. maraenoides and C. holsatus. Similarly, supplementary stocking in a south-eastern Finnish watercourse has contributed to a high degree of genetic admixture between originally distinct whitefish [71], and translocation of Baltic whitefish into Austrian Alpine lakes has created hybrids [72]. In contrast, weak introgression from Siberian Coregonus peled into local lake whitefish populations was found in Poland, despite artificial fertilization in hatcheries [73]. Accordingly, the degree of hybridization between native and introduced species of whitefish seems to be difficult to predict.

In 1948, Lenz [26] reported that C. maraenoides is better adapted to eutrophic lakes and that stocking of artificially reared $C$. maraenoides gained higher yields than stocking of C. holsatus. Thus it is possible that C. maraenoides was preferred for artificial reproduction by commercial fishermen, since both species are easy to distinguish by mouth and body shape. When both lakes became strongly eutrophic preventing ultimately the natural reproduction of all whitefish species [74], the native $C$. holsatus may have vanished while the introduced $C$. maraenoides was kept by artificial reproduction. Stocking measures in combination with anthropogenically induced environmental changes have been presumed responsible for the extinction of several other indigenous populations of Salmoniformes in Europe [19, 34, 70, 75, 76]. In Lake Drewitz, C. holsatus may have proliferated because in this lake the only other coregonid species occurring is the much smaller vendace C. albula [19], whereas whitefish were absent, and $C$. maraenoides was never stocked.
To test Thienemann's assumption that $C$. holsatus is an independent species we compared the historical C. holsatus specimens with contemporary whitefish species in North and Central Europe. Our limited dataset does not allow resolving the diversity of all northern whitefish, but we can unambiguously refute that $C$. holsatus is the same evolutionary unit as any other contemporary whitefish studied here. We could not confirm that $C$. holsatus and C. widegreni are conspecific [22]. The Finnish sea-spawning whitefish from Oulu named as $C$. widegreni included into this study was genetically significantly differentiated from the contemporary Lake Drewitz whitefish (C. holsatus translocated from Lake Schaal). Furthermore, in the NJ tree, the Oulu sea-spawning whitefish grouped with contemporary anadromous whitefish from the Baltic (Achterwasser, Schlei and Trave), the North Sea (River Treene) and the Lake Constance whitefish populations. More studies are needed to identify the phylogeography of C. widegreni in the context of other Scandinavian and Russian anadromous whitefish species.

As a consequence of the broad variety of whitefish populations studied, we could also explore the genetic relationships of anadromous whitefish from the south-western Baltic and eastern North Sea basins for conservation purposes. In the south-western Baltic Sea basin, only one population of anadromous whitefish has survived in the lower Peene/Odra drainage [77]. This species was preliminarily identified as C. maraena [29]. The whitefish from Achterwasser included in our study belong to this population. Since 1992, fish from this population have been stocked into the German Rivers Schlei and Trave [27], and the admixture between these three populations is reflected in the individual assignment as based on the DAPC. In contrast, in the entire North Sea basin, anadromous whitefish have only survived in the Danish river Vida [78, 79]. Since 1987, brood-stock of this Vida population has been used for several reintroduction programs in Danish and German North Sea tributaries including the River Rhine [80]. River Vida is also the origin of the whitefish from River Treene included in our study $[35,80]$. In the DAPC plot, the River Treene whitefish were closely located to $C$. widegreni from Oulu and C. holsatus from Lake Drewitz and next to River Trave C. maraena, but the proportion of individual self-assignment to River Treene in the DAPC was almost $100 \%$. In the NJ tree, River Treene whitefish primarily grouped with Lake Constance whitefish populations, whereas the next branch consisted of the anadromous whitefish C. maraena from the German Baltic Sea coast (Achterwasser, Schlei and Trave). Previously, the River Treene whitefish have likewise preliminarily been identified as C. maraena [29], and therefore it was suggested that all contemporary anadromous whitefish populations in the Baltic and North Sea can be 
considered as C. maraena. This conclusion was supported by Hansen et al. [30, 81] who found only small differences of mitochondrial DNA and microsatellite markers between whitefish from the Baltic and North Sea basins.

A recent admixture analysis suggested a hybrid zone between River Vida whitefish, C. maraena from River Peene/ Odra (identical to Achterwasser and Rivers Schlei and Trave in our study) and whitefish from north German lakes, including Lake Poenitzer, potentially caused by erroneous stocking with non-native genotypes [69]. Admixture may also be caused by escaped larvae of River Treene whitefish, which were raised in netcages in Lake Keller [80]. The assignment of fish as based on the DAPC in our study supported that single individuals may represent hybrids between whitefish in Lake Schaal (identified as C. maraenoides in our study) and C. maraena from River Trave. However, by sequencing the whole mitochondrial genome, recent strong reproductive isolation between Danish North Sea populations from River Vida and the Baltic lake whitefish $C$. lavaretus complex (including fish from Achterwasser, named as C. maraena in our study) has been demonstrated [82]. This study [82] corresponds with the distinct branching in the NJ tree between the contemporary C. c.f. maraena from the River Vida and C. maraena from the three Baltic Sea populations (Achterwasser, Schlei and Trave), although the bootstrap support was low (about 30\%). Overall, the genetic similarity was higher between River Treene whitefish and C. maraena from River Trave, than between River Treene whitefish and $C$. maraena from Achterwasser, the original source of stocked whitefish in River Trave.

The 14 historical $C$. oxyrinchus individuals were assigned primarily to the contemporary $C$. maraena populations ( 7 of 14 individuals with $>50 \%$ assignment), whereas only one individual was assigned to the contemporary River Treene population, which is usually identified as $C$. oxyrinchus. Similarly, the historical $C$. oxyrinchus individuals were grouped next to the three $C$. maraena populations in the $\mathrm{NJ}$ tree. This suggests a weaker genetic differentiation between contemporary $C$. maraena and historical C. oxyrinchus than between contemporary anadromous River Vida/Treene and historical C. oxyrinchus populations. This has clear implications for the current stocking programs in the North Sea tributaries. According to our data, the fish currently stocked into the River Rhine [80] from River Vida cannot be treated as re-introduction of C. oxyrinchus [29], as the historical specimens of $C$. oxyrinchus are genetically fairly distinct from contemporary River Treene/Vida whitefish. However, it has to be stressed that the bootstrap support for the major branching in the NJ tree among all anadromous populations including the historical $C$. oxyrinchus was very low.

Based on morphological data, Freyhof \& Schöter [29] have supported Redeke's [83] and Thienemann's [84] assumption that historically two species of anadromous whitefish may have been present in the North Sea basin: $C$. oxyrinchus in England and in the Rivers Rhine, Meuse and Schelde, and C. maraena migrating along the rivers east of the Rhine (eastern North Sea and Baltic basins). The scattered assignment of the 14 historical western houting individuals (named as C. oxyrinchus) to contemporary anadromous and lake-resident whitefish suggests that this distinction between C. maraena and C. oxyrinchus within the North Sea basins is less clear than assumed. We can only speculate about the background of these findings. For the nineteenth century when the historical material of $C$. oxyrinchus had been sampled, there is no reported stocking in the geographical range where $C$. oxyrinchus has occurred. However, we cannot exclude that $C$. oxyrinchus has experienced introgressive hybridisation involving genes from Lake Constance whitefish (as suggested by the assignment by Geneclass2), which have always also occurred in the lower Rhine, as well as from $C$. maraena straying from the east (as suggested by the assignment from both DAPC and Geneclass2). We encourage future in-depth studies to test for introgression of adjacent species into C. oxyrinchus. A broader spatial scale and exactly defined geographical origin of historical and contemporary samples from anadromous whitefishes of the Baltic and North Sea tributaries would help resolving the complex phylogeography of these northern and middle European whitefish species and populations.

\section{Conclusions}

Stocking and translocations which have begun at least 100 years ago have modified the recent genetic signature of many whitefish species and populations. In some cases, local populations vanished and were replaced by stocked whitefish species originating from other sources. The often poorly documented stocking history and the unpredictability of stocking success contribute to the unresolved conservation status for many whitefish species and populations. To facilitate informed decisions on the conservation of evolutionarily significant units within the whitefish complex, further comparative genetic studies of contemporary and historical material are urgently needed.

\section{Additional file}

Additional file 1: Table S1. Geographical coordinates (degrees), catchment, basin and mean depth and surface area (for lakes only) of aquatic systems, from which the Coregonus populations were sampled. Table S2. $P$-values of deviations from Hardy-Weinberg equilibrium per locus and population, as controlled by the false discovery rate for multiple tests. Table S3. Matrix of pairwise $\theta$ between the 15 contemporary whitefish populations (below diagonal), and their lower 95\% confidence intervals (above diagonal). Strong structure between populations is indicated in bold, as evidenced by the lower Cl not including zero. For population origin, see Table 1. L. Const= Lake Constance. (DOCX 29 kb) 


\section{Abbreviations}

AMOVA: Analysis of Molecular Variance; $A_{N}$ : Number of alleles; $A_{R}$ : Allelic richness; Cl: Confidence interval; $D_{A}$ : Nei's genetic distance; DAPC: Discriminant Analysis of Principal Components; $F_{15}$ : Inbreeding coefficient; HWE: Hardy-Weinberg equilibrium; NJ dendrogram: Neighborjoining dendrogram; rD: Index of association with an approximation for the number of loci; ZMB: Zoological Museum of Berlin, Germany

\section{Acknowledgements}

We would like to thank Michael T. Monaghan for helpful comments on an earlier version of this manuscript, E. Jakob for help with laboratory work, K.J. Himberg for making field work in Finland possible, and R. Lemcke, T. Schaarschmidt and H.-J. Jennerich for logistic support and discussion.

\section{Funding}

Research was funded by grants from the German Bundesländer Mecklenburg-Vorpommern and Schleswig-Holstein and in part from a grant within the priority program Aquashift of the German Research Council (DFG, Project Numbers Me 1686/5-1+2). However, funding bodies did not contribute to design of the study and sample collection, analysis, and interpretation of data and in writing the manuscript. The publication of this article was funded by the Open Access Fund of the Leibniz Association and the Open Access Fund of the Leibniz-Institute of Freshwater Ecology and Inland Fisheries (IGB)

\section{Availability of data and materials}

The dataset generated and analyzed during the current study is made available in the DRYAD repository at https://doi.org/10.5061/dryad.4d79f7h.

\section{Authors' contributions}

$\mathrm{TM}, \mathrm{KP}$ and JF initiated the project and planned its design. $\mathrm{KP}$ and $\mathrm{DB}$ performed the laboratory analyses. TM and KP performed the statistical analyses and wrote the text. All authors commented on the text and approved the final version.

\section{Ethics approval and consent to participate}

A permit for collecting fish samples was not needed, because all fish from contemporary populations were taken from the catch of commercial fishermen. No fish was killed for the purpose of this study.

\section{Consent for publication}

Not applicable.

\section{Competing interests}

The authors declare that they have no competing interests.

\section{Publisher's Note}

Springer Nature remains neutral with regard to jurisdictional claims in published maps and institutional affiliations.

\section{Author details \\ 'Leibniz-Institute of Freshwater Ecology and Inland Fisheries, Müggelseedamm 310, 12587 Berlin, Germany. ${ }^{2}$ Department of Fish Ecology \& Evolution, Centre of Ecology, Evolution and Biogeochemistry, EAWAG Swiss Federal Institute of Aquatic Science and Technology, Seestrasse 79, 6047 Kastanienbaum, Switzerland. ${ }^{3}$ Present address: Kanton Aargau, Departement Bau, Verkehr und Umwelt, Abteilung Wald, Jagd und Fischerei, Entfelderstrasse 22, 5001 Aarau, Switzerland.}

Received: 6 July 2018 Accepted: 18 December 2018 Published online: 29 December 2018

\section{References}

1. Steinmann P. Monographie der Schweizerischen Koregonen. Beitrag zum Problem der Entstehung neuer Arten. Einleitung. Schweiz Z Hydrol. 1950;12: 109-89.

2. Steinmann P. Monographie der schweizerischen Koregonen. Beitrag zum Problem der Entstehung neuer Arten. Spezieller Teil (1st part). Schweiz Z Hydrol. 1950;12:340-491.
3. Steinmann P. Monographie der Schweizerischen Koregonen. Beitrag zum Problem der Entstehung neuer Arten. Spezieller Teil (2nd part). Schweiz Z Hydrol. 1951;13:54-191.

4. Svärdson G. The coregonid problem. VI. The Palearctic species and their intergrades. Rep Inst Freshwat Res Drottningholm. 1957;38:267-356.

5. Svärdson G. Postglacial dispersal and reticulate evolution of Nordic coregonids. Nord J Freshwat Res. 1998;74:3-32.

6. Berg LS. [Freshwater fishes of the U.S.S.R. and adjacent countries] vol. 1 [translation: Israel program for scientific translations, Jerusalem, 1962]. Moskva \& Leningrad: Izdatelstvo Akademii Nauk SSSR; 1948.

7. Reshetnikov YS. Coregonid fishes in recent conditions. Finn Fish Res. 1968;9: $11-6$.

8. Himberg KJM, Lehtonen H. Systematic and nomenclature of coregonid fishes. Particularly in Northwest Europe. Archiv für Hydrobiologie Special Issues Advances of Limnology. 1995;46:39-47.

9. Douglas MR, Brunner PC, Bernatchez L. Do assemblages of Coregonus (Teleostei: Salmoniformes) in the central alpine region of Europe represent species flocks? Mol Ecol. 1999;8(4):589-603.

10. Ostbye K, Bernatchez L, Naesje TF, Himberg KJM, Hindar K. Evolutionary history of the European whitefish Coregonus lavaretus (L.) species complex as inferred from mtDNA phylogeography and gill-raker numbers. Mol Ecol. 2005;14(14):4371-87.

11. Hudson AG, Vonlanthen P, Müller R, Seehausen O. Review: the geography of speciation and adaptive radiation in coregonines. Archiv für Hydrobiologie Special Issues Advances Limnology. 2007;60:111-46.

12. Schulz M, Freyhof J, Saint-Laurent R, Østbye K, Mehner T, Bernatchez L. Evidence for independent origin of two spring-spawning ciscoes in Germany (Salmoniformes: Coregonidae). J Fish Biol. 2006;68(Suppl. A):119-35.

13. Hudson $A G$, Vonlanthen $P$, Seehausen $O$. Rapid parallel adaptive radiations from a single hybridogenic ancestral population. P Roy Soc B-Biol Sci. 2011; 278. https://doi.org/10.1098/rspb.2010.0925):58-66.

14. Mehner T, Pohlmann K, Elkin C, Monaghan MT, Nitz B, Freyhof J. Genetic population structure of sympatric and allopatric populations of Baltic ciscoes (Coregonus albula complex, Teleostei, Coregonidae). BMC Evol Biol. 2010;10:85.

15. Bittner D, Excoffier $L$, Largiader CR. Patterns of morphological changes and hybridization between sympatric whitefish morphs (Coregonus spp.) in a Swiss lake: a role for eutrophication? Mol Ecol. 2010;19(10):2152-67.

16. Wagler E. Die Coregonen in den Seen des Voralpengebietes. IX. Die Systematik der Voralpencoregonen. Internationale Revue der Gesamten Hydrobiologie und Hydrographie. 1937;35:345-446.

17. Wagler E. Die Lachsartigen (Salmonidae) II. Teil. Coregonen. In: Handbuch der Binnenfischerei Mitteleuropas. In: Demoll R, Maier HH, editors. Handbuch der Binnenfischerei Mitteleuropas, Vol IIIA. Stuttgart: Schweizerbarth; 1941. p. 371-501.

18. Vogt C, Hofer B. Die Süßwasserfische von Mitteleuropa. Teil I. Leipzig: Commissions Verlag Wilhelm Engelmann; 1909.

19. Mehner T, Pohlmann K, Elkin C, Monaghan MT, Freyhof J. Genetic mixing from enhancement stocking in commercially exploited vendace populations. J Appl Ecol. 2009;46:1340-9.

20. Thienemann A. Die Unterschiede zwischen der großen Maräne des Madüsees und des Selentersees. Zool Anz. 1916;48:97-101.

21. Thienemann A. Über einige schwedische Coregonen mit Bemerkungen über die Systematik der Gattung Coregonus und die Wege und Ziele der künftigen Coregonenforschung. Archiv für Naturgeschichte Berlin Abt A. 1921;87:170-95.

22. Kottelat M. European freshwater fishes. An heuristic checklist of the freshwater fishes of Europe (exclusive of former USSR), with an introduction for non-systematists and comments on nomenclature and conservation. Biologia Bratislava, SectZool. 1997;52(Suppl. 5):1-271.

23. Svärdson G. Speciation of the Scandinavian Coregonus Reports of the Institute of Freshwater Research Drottningholm. 1979; 57:1-95.

24. Siemssen AC. Verzeichnis der Fische, welche im Schall-See und im Schall Flusse vorkommen. Beylagen zu den wöchentlichen Rostockschen Nachrichten und Anzeigen. 1817:100.

25. Dröscher W. Der Schaalsee und seine fischereiwirtschaftliche Nutzung. Zeitschrift für Fischerei. 1907:13:172-283.

26. Lenz J. Die Edelmaräne in den Plöner Seen. Archiv für Fischereiwissenschaften. 1948;1:163-73.

27. Spratte S, Hartmann U. Fischartenkataster. Süßwasserfische und Neunaugen in Schleswig-Holstein. Kiel: Ministerium für ländliche Räume, Landwirtschaft, Ernährung und Tourismus des Landes Schleswig-Holstein; 1997. 
28. Kottelat M, Bogutskaya NG, Freyhof J. On the migratory Black Sea lamprey and the nomenclature of the ludoga, Peipus and ripus whitefishes (Teleostei: Petromyzonidae and Coregonidae). Zootaxonomica Rossica 2005; ??:181-186.

29. Freyhof J, Schöter C. The houting Coregonus oxyrinchus (L.) (Salmoniformes: Coregonidae), a globally extinct species from the North Sea basin. J Fish Biol. 2005;67(3):713-29.

30. Hansen MM, Fraser DJ, Als TD, Mensberg KLD. Reproductive isolation, evolutionary distinctiveness and setting conservation priorities: the case of European lake whitefish and the endangered North Sea houting (Coregonus spp.). BMC Evol Biol. 2008;8.

31. Grøn P. Saving the North Sea houting. In: Proceedings of the 5th International Wadden Sea Symposium. Edited by Tougaard S, Asbirk S. Esbjerg. 1987;146-159.

32. Vonlanthen $P$, Roy D, Hudson AG, Largiader CR, Bittner D, Seehausen O. Divergence along a steep ecological gradient in lake whitefish (Coregonus sp.). J Evol Biol. 2009:22(3):498-514.

33. Kottelat M, Freyhof J. Handbook of European freshwater fishes. Cornot and Berlin: Kottelat and Freyhof; 2007.

34. Vonlanthen P, Bittner D, Hudson AG, Young KA, Muller R, LundsgaardHansen B, Roy D, Di Piazza S, Largiader CR, Seehausen O. Eutrophication causes speciation reversal in whitefish adaptive radiations. Nature. 2012; 482(7385):357-62.

35. Jäger T. Die Wiedereinbürgerung des Nordseeschnäpels. In: Fisch des Jahres 1999: Der Nordseeschnäpel. Offenbach: Verband Deutscher Sportfischer; 1999. p. 3-11

36. Schander C, Halanych KM. DNA, PCR and formalinized animal tissue - a short review and protocols. Org Divers Evol. 2003:3(3):195-205.

37. Turgeon J, Estoup A, Bernatchez L. Species flock in the north American Great Lakes: molecular ecology of Lake Nipigon ciscoes (Teleostei: Coregonidae: Coregonus). Evolution. 1999;53(6):1857-71.

38. Rogers SM, Marchand MH, Bernatchez L. Isolation, characterization and cross-salmonid amplification of 31 microsatellite loci in the lake whitefish (Coregonus clupeaformis, Mitchill). Mol Ecol Notes. 2004;4(1):89-92.

39. Patton JC, Gallaway RG, Fechhelm RG, Cronin MA. Genetic variation of microsatellite and mitochondrial DNA markers in broad whitefish (Coregonus nasus) in the Colville and Sagavanirkrtok Rivers in northern Alaska. Can J Fish Aquat Sci. 1997;45:1548-56.

40. Patton JC, Gallaway BJ, Fechhelm RG, Cronin MA. Genetic variation of microsatellite and mitochondrial DNA markers in broad whitefish (Coregonus nasus) in the Colville and Sagavanirktok rivers in northern Alaska. Can J Fish Aquat Sci. 1997;54:1548-56.

41. R Development Core team. R: a language and environment for statistical computing. Vienna: R Foundation for statistical Computing; 2017.

42. ElMousadik A, Petit RJ. High level of genetic differentiation for allelic richness among populations of the argan tree [Argania spinosa $(\mathrm{L})$ Skeels] endemic to Morocco. Theor Appl Genet. 1996;92(7):832-9.

43. Adamack AT, Gruber B. PopGenReport: simplifying basic population genetic analyses in R. Methods Ecol Evol. 2014;5(4):384-7.

44. Raymond M, Rousset F. Genepop (Version-1.2) - population genetics software for exact tests and ecumenicism. J Hered. 1995;86(3):248-9.

45. Rousset F. GENEPOP ' 007: a complete re-implementation of the GENEPOP software for windows and Linux. Mol Ecol Resour. 2008:8(1):103-6.

46. Guo SW, Thompson EA. Performing the exact test of hardy-Weinberg proportion for multiple alleles. Biometrics. 1992:48(2):361-72.

47. Benjamini $Y$, Hochberg Y. Controlling the false discovery rate - a practical and powerful approach to multiple testing. J Roy Stat Soc B Met. 1995;57(1): 289-300.

48. Agapow PM, Burt A. Indices of multilocus linkage disequilibrium. Mol Ecol Notes. 2001;1(1-2):101-2.

49. Kamvar ZN, Tabima JF, Grunwald NJ. Poppr: an R package for genetic analysis of populations with clonal, partially clonal, and/or sexual reproduction. Peerj. 2014;2:e281.

50. Kamvar ZN, Brooks JC, Grunwald NJ. Novel R tools for analysis of genomewide population genetic data with emphasis on clonality. Front Genet. 2015;6:208.

51. Jombart T, Devillard S, Balloux F. Discriminant analysis of principal components: a new method for the analysis of genetically structured populations. BMC Genet. 2010;11:94.

52. Pritchard JK, Stephens M, Donnelly P. Inference of population structure using multilocus genotype data. Genetics. 2000;155(2):945-59.
53. Jombart T. Adegenet: a R package for the multivariate analysis of genetic markers. Bioinformatics. 2008;24(11):1403-5.

54. Jombart T, Ahmed I. Adegenet 1.3-1: new tools for the analysis of genomewide SNP data. Bioinformatics. 2011;27(21):3070-1.

55. Excoffier L, Smouse PE, Quattro JM. Analysis of molecular variance inferred from metric distances among DNA haplotypes - application to human mitochondrial-DNA restriction data. Genetics. 1992;131(2):479-91.

56. Paradis E. Pegas: an R package for population genetics with an integratedmodular approach. Bioinformatics. 2010;26(3):419-20.

57. Weir BS, Cockerham CC. Estimating F-statistics for the analysis of population structure. Evolution. 1984;38(6):1358-70.

58. Keenan K, McGinnity P, Cross TF, Crozier WW, Prodohl PA. diveRsity: an R package for the estimation and exploration of population genetics parameters and their associated errors. Methods Ecol Evol. 2013;4(8):782-8.

59. Piry S, Alapetite A, Cornuet JM, Paetkau D, Baudouin L, Estoup A. GENECLASS2: a software for genetic assignment and first-generation migrant detection. J Hered. 2004;95(6):536-9.

60. Baudouin L, Lebrun P. An operational bayesian approach for the identification of sexually reproduced cross-fertilized populations using molecular markers. Acta Hortic. 2000;546:81-93.

61. Nei M, Tajima F, Tateno Y. Accuracy of estimated phylogenetic trees from molecular data. 2. Gene-frequency data. J Mol Evol. 1983;19(2):153-70.

62. Wahlund S. Zuzammensetzung von Populationen und Korrelationserscheinungen vom Standpunkt der Vererbungslehre aus betrachtet. Hereditas. 1928;11:65-106.

63. Garnier-Géré P, Chikhi L. Population subdivision, hardy-Weinberg equilibrium and the Wahlund effect. eLS (http://www.els.net/WileyCDA/). Chichester: John Wiley and Sons; 2013.

64. Beaumont AR, Bray J, Murphy JM, Winfield IJ. Genetics of whitefish and vendace in England and Wales. J Fish Biol. 1995:46(5):880-90.

65. Wilson AJ, Gislason D, Skulason S, Snorrason SS, Adams CE, Alexander G, Danzmann RG, Ferguson MM. Population genetic structure of Arctic Charr, Salvelinus alpinus from Northwest Europe on large and small spatial scales. Mol Ecol. 2004;13(5):1129-42.

66. Castric V, Bernatchez L, Belkhir K, Bonhomme F. Heterozygote deficiencies in small lacustrine populations of brook charr Salvelinus fontinalis Mitchill (Pisces, Salmonidae): a test of alternative hypotheses. Heredity. 2002;89:27-35.

67. Verspoor E, Coulson MW, Greer RB, Knox D. Unique sympatric quartet of limnetic, benthic, profundal and piscivorous brown trout populations resolved by $3 \mathrm{D}$ sampling and focused molecular marker selection. Freshwat Biol. 2018; in press.

68. Winkler HM, Waterstraat A, Hamann N. Rote Liste des Landes MN Rundmäuler, Süßwasserfische und Wanderfischarten. Rostock: Umweltministerium Mecklenburg-Vorpommern; 2002.

69. Dierking J, Phelps L, Praebel K, Ramm G, Prigge E, Borcherding J, Brunke M, Eizaguirre C. Anthropogenic hybridization between endangered migratory and commercially harvested stationary whitefish taxa (Coregonus spp.). Evol Appl. 2014;7(9):1068-83.

70. Brämick U, Diekmann M, Lemcke R, Mehner T. Assessing shifts in fish assemblage composition in German large lakes by literature data and commercial catch statistics. Fundamental and Applied Limnology - Archiv für Hydrobiologie. 2008;171:87-103

71. Huuskonen $\mathrm{H}$, Shikano T, Mehtatalo L, Kettunen J, Eronen R, Toiviainen A, Kekaelaeinen J. Anthropogenic environmental changes induce introgression in sympatric whitefish ecotypes. Biol J Linn Soc. 2017;121(3):613-26.

72. Winkler KA, Pamminger-Lahnsteiner B, Wanzenböck J, Weiss S. Hybridization and restricted gene flow between native and introduced stocks of alpine whitefish (Coregonus sp.) across multiple environments. Mol Ecol. 2011;20:456-72.

73. Popovic D, Szczepkowski M, Heese T, Weglenski P. Introgression of peled (Coregonus peled) into European whitefish (C. lavaretus) in Poland. Conserv Genet. 2016;17(2):503-8

74. Müller R. Trophic state and its implications for natural reproduction of salmonid fish. Hydrobiologia. 1992;243:261-8.

75. Douglas MR, Brunner PC. Biodiversity of central alpine Coregonus (Salmoniformes): impact of one-hundred years of management. Ecol Appl. 2002;12(1):154-72.

76. Englbrecht CC, Schliewen U, Tautz D. The impact of stocking on the genetic integrity of Arctic charr (Salvelinus) populations from the alpine region. Mol Ecol. 2002:11(6):1017-27.

77. Freyhof J. Rote Liste der im Süßwasser reproduzierenden Neunaugen und Fische (Cyclostomata \& Pisces), fünfte Fassung. Naturschutz und Biologische Vielfalt. 2009;70:291-316 
78. Lelek A. The freshwater fishes of Europe. Vol 9. Threatened fishes of Europe. Wiesbaden: Aula; 1987.

79. Maitland PS, Lyle AA. Conservation of freshwater fish in the British-isles - the current status and biology of threatened species. Aquat Conserv. 1991;1(1): 25-54.

80. Borcherding J, Heynen M, Jaeger-Kleinicke T, Winter HV, Eckmann R. Reestablishment of the North Sea houting in the river Rhine. Fish Manage Ecol. 2010;17(3):291-3.

81. Hansen MM, Mensberg KLD, Berg S. Postglacial recolonization patterns and genetic relationships among whitefish (Coregonus sp.) populations in Denmark, inferred from mitochondrial DNA and microsatellite markers. Mol Ecol. 1999;8(2):239-52.

82. Jacobsen MW, Hansen MM, Orlando L, Bekkevold D, Bernatchez L, Willerslev E, Gilbert MTP. Mitogenome sequencing reveals shallow evolutionary histories and recent divergence time between morphologically and ecologically distinct European whitefish (Coregonus spp.). Mol Ecol. 2012; 21(11):2727-42.

83. Redeke HC. Über den Rheinschnäpel, Coregonus oxyrhynchus L. Verhandlungen der Internationalen Vereinigung für Limnologie. 1934;6:352-7.

84. Thienemann A. Die Schlei und ihre Fischereiwirtschaft. Der Schleischnäpel (Coregonus lavaretus balticus). Schriftenreihe des Naturwissenschaftlichen Vereins Schleswig-Holstein. 1937;32:190-208.

Ready to submit your research? Choose BMC and benefit from:

- fast, convenient online submission

- thorough peer review by experienced researchers in your field

- rapid publication on acceptance

- support for research data, including large and complex data types

- gold Open Access which fosters wider collaboration and increased citations

- maximum visibility for your research: over $100 \mathrm{M}$ website views per year

At BMC, research is always in progress.

Learn more biomedcentral.com/submissions 